\title{
The Impact of Rural Electrification on Education: A Case Study from Peru
}

\section{Julio Aguirre*}

\begin{abstract}
This study examines the indirect impact of rural electrification on education. It finds that the greater the likelihood of a household being connected to the electricity grid, the more time the household's children are likely to spend studying at home. This finding is interpreted as indirect evidence of an improvement in levels of schooling. Using instrumental variables to overcome endogeneity problems, the study's LATE estimates reveal that providing households with access to electricity leads to children studying an extra $94-137$ minutes at home per day, on average.
\end{abstract}

Keywords: rural electrification, infrastructure, education, Peru.

JEL classification: O12, C31, C81.

\section{Introduction}

The impact of rural electrification programs has received considerable attention in the literature as well as among policymakers aiming to ensure that public resources are allocated optimally. In both cases, the conclusion is the same: rural electrification generates substantial and favorable changes in welfare and is deemed a prerequisite for economic growth. A range of studies support this idea, including Khandker et al. (2012); the Asian Development Bank (2010); Meier et al. (2010); the World Bank (2002); Cabraal, Barnes and Agarwal (2005); Martins (2005); and Barnes, Peskin and Fitzgerald (2003).

The literature divides the benefits of electricity into two categories: direct and indirect. The first includes improved lighting and the wider use of amenities such as television, radio and refrigeration. The second includes better educational outcomes, greater opportunities for income generation, lower fertility rates (Peters \& Vance, 2011) and better health outcomes (by

* Research Center, Universidad del Pacífico, Lima, Peru.

I am grateful to the Ministerio de Energía y Minas and the Organismo Supervisor de la Inversión en Energía y Minería in Peru for the data and geo-spatial information used in this study. 
reducing indoor air pollution and enabling vaccines to be cold-stored). The Independent Evaluation Group (IEG) (2008) describes the direct impact of rural electrification in terms of improving the quality of services provided by schools that use electricity-dependent equipment, and the indirect impact in terms of increasing the time allocated to studying at home or the availability of educational programs on TV.

This study examines the impact of rural electrification on schooling by looking at the relationship between the proportion of rural households connected to the electricity grid and the time children spend studying at home. Drawing on a unique survey of energy use in Peru conducted by Urrunaga et al. (2013), the study finds that household access to electricity increases the time children spend studying at home, which can be interpreted as indirect evidence of an improvement in schooling.

Broadly, the literature supports the idea that children living in households with access to electricity are better educated than those in households with no electricity. For a sample of households in Peru, Meier et al. (2010) observe that school-going children aged 6-18 years, living in households with access to electricity, spend an average of 65 minutes reading and/or studying every evening, whereas those in households without electricity spend 51 minutes on such activities - the difference is found to be statistically significant. The IEG (2008) employs standardized demographic and health surveys carried out in nine countries and finds that, on average, access to electricity is associated with children spending more than 70 minutes a day studying at home. ${ }^{1}$

In 2006, Peru initiated a series of rural electrification programs under the Ley General de Electrificación (Law of General Rural Electrification). This was done in coordination with regional and local governments to provide villages (populated centers) and rural households with access to energy. The Ministerio de Energía y Minas del Perú (MEM), through the Dirección General de Electrificación Rural (DGER), established a set of criteria for targeting rural areas: (i) the coefficient of provincial rural electrification (lowest), (ii) the poverty rate (highest), (iii) the amount of the subsidy required to connect the area and (iv) the density of the population. Many rural electrification programs were implemented between 1993 and 2013, with the last one scheduled for 2008-17.2 To date, Peru has invested

\footnotetext{
${ }^{1}$ Bangladesh, Ghana, Indonesia, Morocco, Nepal, Nicaragua, Peru, the Philippines and Senegal.

${ }^{2}$ It is important to note that these programs were carried out in populated villages, given that rural households in Peru tend to locate near the district capital or the land they cultivate. This has implications
} 
US\$278.6 million in such programs: 5,340 villages have been connected to the electricity grid and the share of rural households with electricity has increased nine-fold from 7.7 percent in 1993 to 70 percent in 2013.3

Between November 2012 and March 2013, the DGER-MEM carried out a study to calculate the social benefits of rural electrification to (i) determine whether public resources were being allocated efficiently, (ii) prioritize funding investments in public projects (to be implemented in 2014), (iii) facilitate the social evaluation of investments in public projects in Peru, and (iv) estimate the direct and indirect benefits of rural electrification. In accordance with the requirements of the DGER, a key component of the study was the Survey of Rural Household Energy Use (SRHEU), conducted in February 2013 (see Urrunaga et al., 2013). Figure 1 maps the locations surveyed.

The importance of accountability in rural electrification programs has increased substantially through more frequent impact evaluation studies and the use of sophisticated methodologies (Ravallion, 2008). Most studies on rural electrification show that it is correlated with development, but do not necessarily demonstrate a causal relationship or account for other variables such as household income:4 see, for example, the World Bank (2002) on the Philippines; Madon and Oey-Gardiner (2002) on Indonesia; and Massé and Samaranayake (2002) on Sri Lanka.

The problem of endogeneity arising in the implementation of rural electrification programs makes it difficult to determine the direction of causality. Following Khandker, Barnes and Samad $(2009,2012)$ and Straub (2015), this study uses the instrumental variable (IV) technique to gauge the net effect of rural electrification, applied to cross-sectional data. Drawing on data from rural household surveys, Khandker et al. $(2009,2012)$ estimate the impact of rural electrification in Bangladesh and India, respectively. Both studies measure welfare outcomes at the household and individual levels,

for the study's methodology in that the distance between a population center and the nearest mediumvoltage pylon does not determine (or rarely so) a household's decision to settle in a particular area.

${ }^{3}$ According to a special report in Diario El Comercio (15 December 2013), these projects included the installation of (i) transmission lines $(60,138$ and $220 \mathrm{kV}$ ) over $2,872 \mathrm{~km}$, (ii) small-scale hydro and thermal generation units (150 MW) and (iii) 1,523 solar panels, as well as the extension of national grid networks and/or isolated electrical systems from which rural systems were developed (see also the National Plan for Rural Electrification for 2013-22).

${ }^{4}$ Straub (2015) points out that the literature fails to address the problem of endogeneity in the case of other infrastructure (transport, for instance). 
including expenditure, income, energy consumption, employment, years of schooling and time spent studying.

Figure 1: Map of surveyed locations

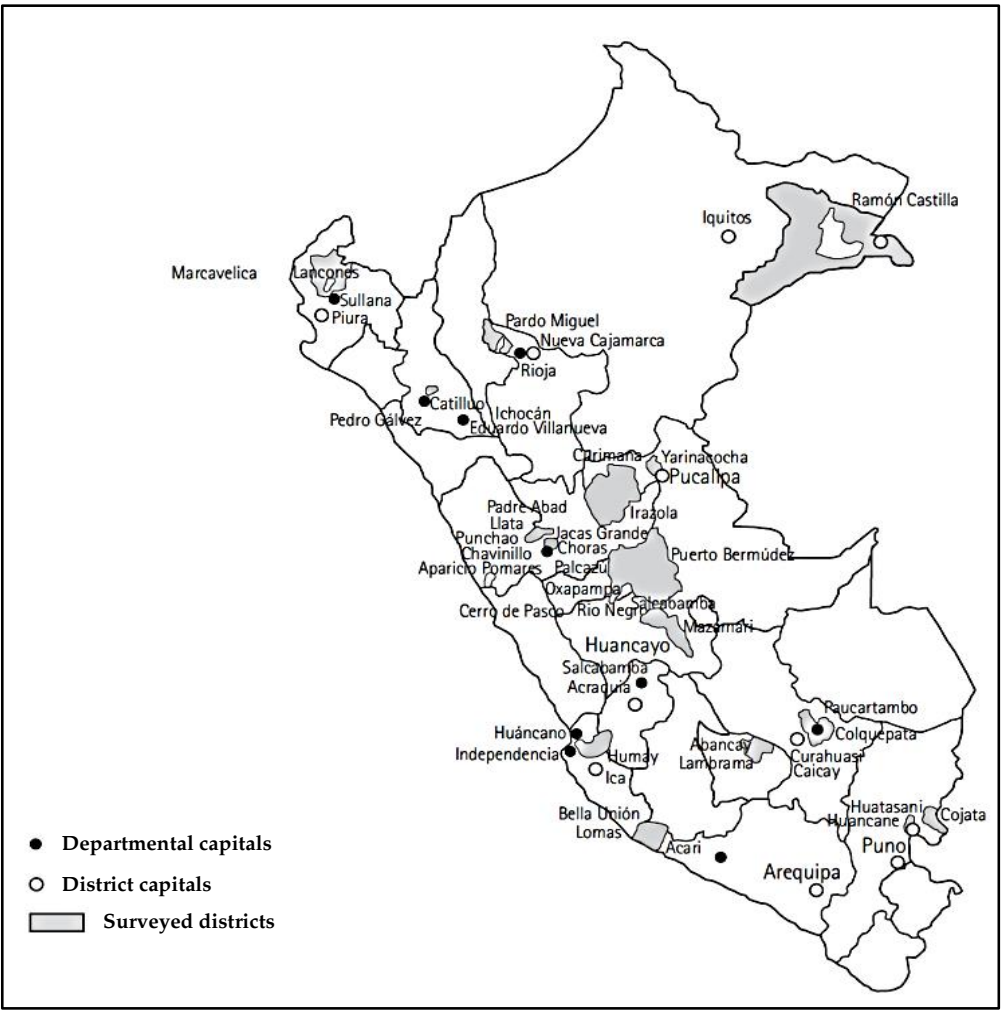

Source: Urrunaga et al. (2013).

While Khandker et al. (2009) use the household's proximity to the nearest electricity line (within or beyond 100 feet) ${ }^{5}$ as an IV (Bangladesh), their 2012 study uses the proportion of households in a community that have access to electricity ${ }^{6}$ (India). ${ }^{7}$ In the first case, they find that access to electricity increases the time boys and girls spend studying by more than six and eight minutes a day, respectively. In the second case, the corresponding increase is equal to more than an hour (and is slightly higher for girls than for boys). The instrument used here is the topographic distance between

\footnotetext{
${ }^{5}$ The distance variable affects whether the household is likely to use grid electricity, but not the outcomes of interest: households located within 100 feet of the electricity line face a lower (subsidized) connection cost, while those beyond 100 feet bear the full cost of connection.

${ }^{6}$ Peer pressure or the demonstration effect is likely to influence a household's decision to apply for a grid connection: households tend to follow the example of their neighbors.

${ }^{7}$ In addition to propensity score matching for Bangladesh and fixed effects for India.
} 
each population center and the nearest medium-voltage line. The IV is correlated with each household's connection status - the shorter the distance, the greater the likelihood of a connection - but not with the time children spend studying at home.

Section 2 describes the data and econometric method used. Section 3 reports the study's results and Section 4 presents its conclusions.

\section{Data and Methodology}

The study draws on data from the SRHEU for 2013, spanning 987 electrified (654) and nonelectrified (333) households across 96 rural population centers in Peru. ${ }^{8}$ The sample is probabilistic and stratified at three stages: by province, district and rural population center. The survey provides data on household composition (household size and each member's age, sex and relationship to the head of the household), levels of education, economic indicators (assets, income and expenditure) and energy use. It also measures how individuals spend their time - in this case, the number of hours children spend studying at home (see Table 1, columns 1-2).

The effects of an electricity connection can be assessed using the conceptual framework of the theory of change (see Bensch, Kluve \& Peters, 2011) under which the household head's decision to apply for a grid connection is linked to a set of outcomes and impacts (for instance, poverty reduction through different channels). Columns 3-6 in Table 1 assess the extent to which the comparability of the household characteristics above translates into heterogeneity between connected and nonconnected households. The p-values in the table show that the test results for the difference in means between connected and nonconnected households are significant for most characteristics.

In focusing solely on the impact of electricity connections on the time primary school-going children spend studying at home, this outcome is treated as an intermediate measure of more tangible outcomes such as academic grades, for which there was no data available. However, it is limited by the consideration that children might also spend this time watching TV or listening to the radio (amenities that run on electricity) notwithstanding the benefits associated with educational programs (IEG, 2008). ${ }^{9}$ The descriptive statistics for this indicator are given in Table 1 and

\footnotetext{
${ }^{8}$ The survey defines a rural population center as comprising 100 contiguous dwellings.

${ }^{9}$ On average, more time is allocated at home to reading than to watching TV or listening to the radio (see Table A1 in the Appendix).
} 
imply that there is a difference between connected and nonconnected households at the national level.

Table 1: Summary statistics

\begin{tabular}{|c|c|c|c|c|c|c|}
\hline Variable & $\begin{array}{c}\text { Mean } \\
1\end{array}$ & $\begin{array}{c}\text { SD } \\
2\end{array}$ & $\begin{array}{c}\mathrm{NC} \\
3\end{array}$ & $\begin{array}{l}\mathrm{C} \\
4\end{array}$ & $\begin{array}{l}\text { Diff. } \\
5\end{array}$ & $\begin{array}{c}\text { p-value } \\
6\end{array}$ \\
\hline \multicolumn{7}{|l|}{ Household characteristics } \\
\hline $\begin{array}{l}\text { Access to electricity }(1=\text { yes, } 0= \\
\text { no })\end{array}$ & 0.337 & 0.473 & & & & \\
\hline $\begin{array}{l}\text { Homeownership }(1=\text { yes, } 0= \\
\text { no) }\end{array}$ & 0.853 & 0.354 & $\begin{array}{c}0.8593 \\
(0.3479)\end{array}$ & $\begin{array}{c}0.8408 \\
(0.3664)\end{array}$ & 0.0185 & 0.0000 \\
\hline $\begin{array}{l}\text { Connected to water network } \\
(1=\text { yes, } 0=\text { no })\end{array}$ & 0.400 & 0.490 & $\begin{array}{c}0.3149 \\
(0.4649)\end{array}$ & $\begin{array}{c}0.5676 \\
(0.4962)\end{array}$ & -0.0320 & 0.0000 \\
\hline $\begin{array}{l}\text { Connected to sanitation network } \\
(1=\text { yes, } 0=\text { no })\end{array}$ & 0.091 & 0.288 & $\begin{array}{c}0.0382 \\
(0.1919)\end{array}$ & $\begin{array}{c}0.1952 \\
(0.3969)\end{array}$ & -0.1569 & 0.0000 \\
\hline $\begin{array}{l}\text { Concrete, wood or corrugated } \\
\text { roof }(1=\text { yes, } 0=\text { no })\end{array}$ & 0.633 & 0.482 & $\begin{array}{c}0.5719 \\
(0.4952)\end{array}$ & $\begin{array}{c}0.7538 \\
(0.4315)\end{array}$ & -0.1819 & 0.0000 \\
\hline Concrete walls $(1=$ yes, $0=$ no $)$ & 0.082 & 0.275 & $\begin{array}{c}0.0459 \\
(0.2094)\end{array}$ & $\begin{array}{c}0.1532 \\
(0.3607)\end{array}$ & -0.1073 & 0.0000 \\
\hline $\begin{array}{l}\text { Concrete or hardwood floors ( } 1 \\
=\text { yes, } 0=\text { no) }\end{array}$ & 0.323 & 0.468 & $\begin{array}{c}0.2982 \\
(0.4578)\end{array}$ & $\begin{array}{c}0.3724 \\
(0.4842)\end{array}$ & -0.0742 & 0.0184 \\
\hline Observations & 987 & & 654 & & 333 & \\
\hline \multicolumn{7}{|l|}{ Household head characteristics } \\
\hline $\begin{array}{l}\text { Time spent living in given } \\
\text { population center }\end{array}$ & 22.867 & 17.791 & $\begin{array}{c}22.7584 \\
(18.2324)\end{array}$ & $\begin{array}{c}23.0778 \\
(16.9200)\end{array}$ & -0.3194 & 0.7907 \\
\hline Education level (years) & 7.176 & 3.921 & $\begin{array}{c}6.9931 \\
(3.8297)\end{array}$ & $\begin{array}{l}7.5360 \\
(4.0759)\end{array}$ & -0.5429 & 0.0396 \\
\hline Age (years) & 45.409 & 15.013 & $\begin{array}{c}44.2324 \\
(14.9276)\end{array}$ & $\begin{array}{c}47.7207 \\
(14.9327)\end{array}$ & -3.4883 & 0.0005 \\
\hline Gender $($ male $=1$, female $=0)$ & 0.881 & 0.323 & $\begin{array}{c}0.8761 \\
(0.3297)\end{array}$ & $\begin{array}{c}0.8919 \\
(0.3109)\end{array}$ & -0.0157 & 0.4699 \\
\hline Household size & 3.806 & 1.763 & $\begin{array}{c}3.7431 \\
(1.8183)\end{array}$ & $\begin{array}{c}3.9309 \\
(1.6441)\end{array}$ & -0.1878 & 0.1136 \\
\hline Observations & 987 & & 654 & & 333 & \\
\hline \multicolumn{7}{|l|}{ Intermediate outcome } \\
\hline $\begin{array}{l}\text { Time children spend studying at } \\
\text { home (average hours per day) }\end{array}$ & 4.091 & 2.414998 & $\begin{array}{l}3.9198 \\
(2.3359)\end{array}$ & $\begin{array}{c}4.3731 \\
(2.4894)\end{array}$ & -0.4533 & 0.0340 \\
\hline Observations & 542 & & 337 & 205 & & \\
\hline
\end{tabular}

Note: $\mathrm{NC}=$ nonconnected households, $\mathrm{C}=$ connected households.

The sample is spread across 97 population centers in 32 districts. On average, each district comprises 3.031 population centers, with a maximum of 10 and a minimum of 1 . On average, each population center includes 10.5 households, with a standard deviation of 9.3. Standard deviations are given in parentheses.

Source: Author's calculations based on data from the SRHEU for 2013.

As explained earlier, the problem of endogeneity can make such electrification programs difficult to evaluate, as comparing outcomes across 
connected and nonconnected households can result in biased parameters (Ravallion, 2008). The decision to connect to the electricity grid is made at the level of the individual household, and may be related to unobserved characteristics that also impact the outcome measured (Peters, 2009). For instance, households with better-educated parents are more likely to bear the cost of applying for an electricity connection because they (i) have greater financial resources and (ii) may assign more importance to the time children spend studying at home. This simultaneity implies that it is not necessarily possible to determine the direction of causality between a household's level of education and its connection status.

While households with access to electricity may have more opportunities available to them, this does not necessarily translate into higher levels of education for their children. Keeping in mind the endogeneity problem and the fact that grid electricity services are made available to relatively developed and densely populated regions before reaching poorer, more remote areas (Khandker et al., 2009), we need to use an IV that is correlated with a household's electricity connection status (the relevance restriction), but not with its outcome variable (the exclusion restriction).

We use the topographic distance between each population center and the nearest medium-voltage line as an instrument for being connected to the electricity grid. This measure was generated using Arcgis 10.1 software and the coordinates locating the transmission lines provided by the Organismo Supervisor de la Inversión en Energía y Minería (OSINERGMIN), which supervises investment in energy and mines in Peru. ${ }^{10}$ The study's hypothesis is that this variable is correlated with the household's connection status - the smaller the distance, the greater the likelihood of a connection - but not with the time children spend studying at home. We use the Hausman test to gauge whether ordinary least squares (OLS) or the IV approach is the better estimation technique in this case.

While we cannot formally test the exclusion restriction, we can examine its validity to the extent of arguing that the instrument violates this restriction, affecting the outcome variable through a channel other than access to electricity. This could include parents' propensity to spend time helping their children with schoolwork (based on their decision to live in a

\footnotetext{
${ }^{10}$ Table A2 in the Appendix, which gives the distances calculated, illustrates the relevance restriction.
} 
relatively developed area) or household income (richer, more densely populated areas tend to be nearer transmission lines). ${ }^{11}$

To maintain the exclusion restriction, Figure 2 assumes that 'rich' and 'poor' households are both located at the same distance from the transmission lines. ${ }^{12}$ Two caveats are worth noting here. First, the survey includes poorer, remote population centers that, in 2013, met the DGERMEM criteria for future rural electrification programs. Second, the fieldwork revealed that some households already had access to electricity either because they were using a different source (such as solar panels) or a different (private) supplier. These caveats are assumed not to affect the study's outcomes because it looks at the impact of access to electricity in general and not that of a specific rural electrification program.

Figure 2: Electricity connections and distance from transmission lines

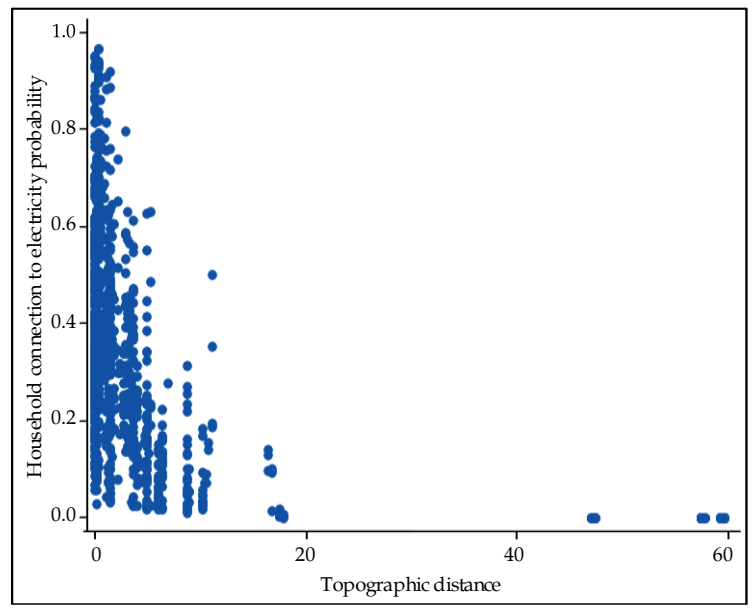

Source: Author's calculations.

\section{Results}

The causal relationship between a rural household's electricity connection status and the time its children spend studying at home is formally written as:

Time spent studying by children ${ }_{\text {ir }}$

$$
=\beta+\alpha \cdot \text { household connection status } i r+\theta \cdot X_{i r}+\delta_{r}+\varepsilon_{i r}
$$

\footnotetext{
${ }^{11}$ Both examples in parentheses are based on a pertinent comment from an anonymous reviewer.

12 The density could not be calculated because there was no data available on the area (in square kilometers) covered by each population center.
} 
where the time spent studying is measured in hours and the subscripts $i$ and $r$ denote the household and region, respectively. $\mathrm{X}$ is a vector of control variables, $\delta_{r}$ is the region effect, $\alpha$ is the average treatment effect and $\varepsilon_{i p r}$ is an error term.

Carrying out an OLS estimation should lead to upward-biased parameters because the unobservable variables are positively correlated with the household's connection status and with the time children spend studying at home. Accordingly, we estimate the equation using two-stage least squares (2SLS), where the endogenous dummy variable 'household connection status' is instrumented by the exogenous variable 'topographic distance'. Figure 3 plots the conditional probability of each household's connection status, given the distance between the village and the nearest transmission line. The most important feature of this figure is the negative relationship between topographic distance and the likelihood of being connected to the electricity grid.

Figure 3: Income intervals, by distance

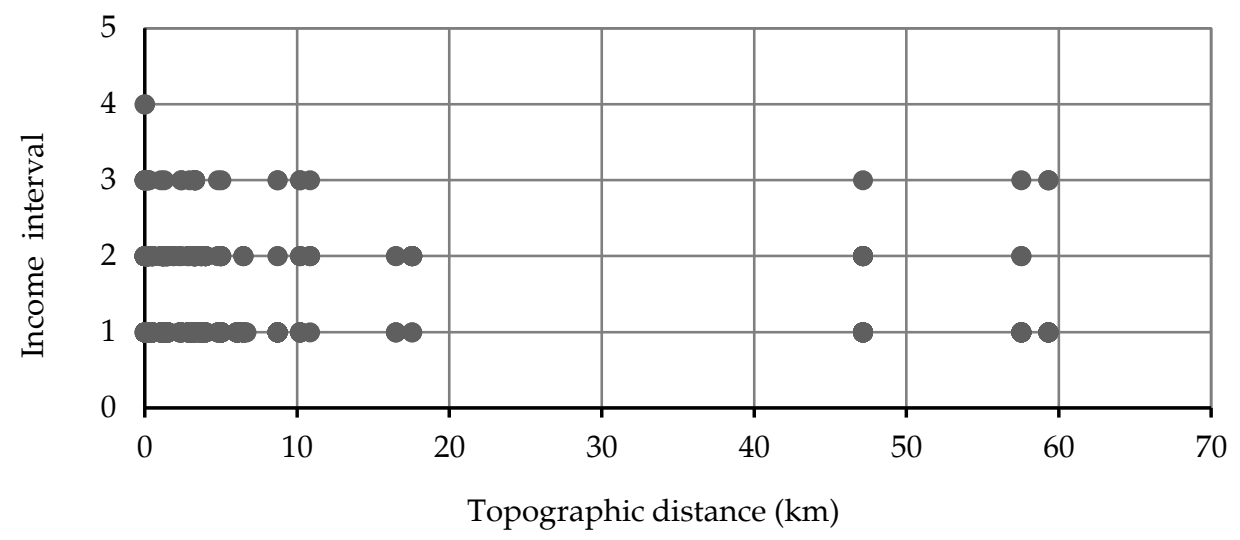

Note: Income interval = 1 for monthly incomes $<$ US\$166, 2 for monthly incomes between US $\$ 166$ and US\$333, 3 for monthly incomes between US\$333 and US\$666, 4 for monthly incomes > US $\$ 666$.

Source: Author's calculations based on data from the SRHEU for 2013.

The first-stage estimates are given in Table 2. The point estimates of the coefficient of topographic distance indicate that the probability of being connected is around 18 percentage points higher for households located in villages nearer a transmission line. The first-stage effect is estimated precisely and is significantly different from 0 . 
Table 2: First-stage results, national level

\begin{tabular}{lll} 
& \multicolumn{1}{c}{ Dependent variable $=$ household's electricity connection } \\
\hline & \multicolumn{1}{c}{ (1) } & \multicolumn{1}{c}{ (2) } \\
\hline Topographic distance & $-0.1830^{* * *}$ & $-0.1823^{* *}$ \\
& $(0.040)$ & $(0.0416)$ \\
Constant & $-1.3257^{* *}$ & $-1.7403^{*}$ \\
& $(0.4387)$ & $(0.4875)$ \\
Household and household head & Yes & Yes \\
characteristics & & \\
$\begin{array}{l}\text { Dummy regions } \\
\text { Method }\end{array}$ & No & Yes \\
$\begin{array}{l}\text { Observations } \\
\text { Wald test }\end{array}$ & Probit & Probit \\
& 537 & 537 \\
\hline
\end{tabular}

Note: Standard errors given in parentheses. ${ }^{*}=$ significant at $10 \%$ level, ${ }^{* *}=$ significant at $5 \%$ level, ${ }^{* * *}=$ significant at $1 \%$ level. Control variables: household head characteristics and household characteristics.

Source: Author's calculations based on data from the SRHEU for 2013.

The IV estimator does not yield the average treatment effect unless one is willing to assume a constant treatment effect. Under sensible assumptions, however, it yields an alternative parameter, the local average treatment effect (LATE) (see Angrist, Imbens \& Rubin, 1996), which is the average effect of treatment on those individuals whose treatment status is changed by the instrument (topographic distance). This applies because households with an electricity connection have obtained one on the basis that their village is near a transmission line - they would not have been connected otherwise. ${ }^{13}$ Thus, the results reported in the table do not need to be generalized across the population of households that, under no circumstances, would have an electricity connection.

Table 3 estimates the impact of having an electricity connection with and without the household head and household characteristics and the dummy regions. As a benchmark, it also reports the reduced-form estimates in columns 3 and 4 .

\footnotetext{
${ }^{13}$ We assume the LATE theorem holds (Imbens \& Angrist, 1994), which states that an instrument that is as good as randomly assigned (i) affects the outcome through a single known channel, (ii) has a first stage and affects the causal channel of interest only in one direction and (iii) can be used to estimate the average causal effect on the affected group (Angrist \& Pischke, 2009).
} 


\section{Table 3: Estimates of the impact of electricity connections on the time children spend studying at home, national level}

\begin{tabular}{|c|c|c|c|c|c|c|}
\hline & (1) & $(2)$ & (3) & (4) & (5) & (6) \\
\hline $\begin{array}{l}\text { Household's electricity } \\
\text { connection }\end{array}$ & $\begin{array}{l}0.399 \\
(0.472)\end{array}$ & $\begin{array}{l}0.739 \\
(0.384)\end{array}$ & & & $\begin{array}{l}1.561^{*} \\
(0.682)\end{array}$ & $\begin{array}{l}2.289^{* * *} \\
(0.564)\end{array}$ \\
\hline Topographic distance & & & $\begin{array}{l}-00246^{*} \\
(0.0099)\end{array}$ & $\begin{array}{l}-0.0418^{* * *} \\
(0.0101)\end{array}$ & & \\
\hline $\begin{array}{l}\text { Household and household } \\
\text { head characteristics }\end{array}$ & Yes & Yes & No & No & Yes & Yes \\
\hline Dummy regions & No & Yes & No & Yes & No & Yes \\
\hline Observations & 537 & 537 & 537 & 537 & 537 & 537 \\
\hline Method & OLS & OLS & OLS & OLS & 2SLS & 2SLS \\
\hline
\end{tabular}

Note: Standard errors given in parentheses. ${ }^{*}=$ significant at $10 \%$ level, ${ }^{* *}=$ significant at $5 \%$ level, ${ }^{* * *}=$ significant at $1 \%$ level. Control variables: household head characteristics and household characteristics. Models (5) and (6) use topographic distance as an IV.

Applying the Hausman test for endogeneity, the null hypothesis is rejected at $5 \%$ in all cases, confirming that 2SLS is the better method. Models (1) and (5): Chi-sq (1) $=6.39$, prob. $>$ Chi-sq $=0.0115$. Models (2) and (6): Chi-sq (1) $=18.96$, prob. $>$ Chi-sq $=0.0000$.

Source: Author's calculations based on data from the SRHEU for 2013.

The 2SLS estimates in columns 5 and 6 indicate that household connections to electricity significantly increase the time children spend studying at home (39.8 and 58.4 percent respectively). ${ }^{14}$ Thus, the IV results suggest that acquiring a connection will allow children to study 93.7 (col 5) to 137.3 (col 6) additional minutes a day relative to those in households without access to electricity. The result of the Hausman test rejects the null hypothesis in these outcomes at the 5 percent level, confirming that the IV technique provides better estimates (consistent) for this sample. The table also reports the OLS results for purposes of comparison.

\section{Conclusion}

The study's aim was to contribute to the literature assessing the impact of rural electrification programs. Using an IV approach to overcome endogeneity concerns, it finds a positive association between rural electrification and the number of hours that school-going children spend studying at home, allowing greater opportunity for improving their academic performance. The findings suggest that the household's access to electricity (in terms of a grid connection) leads to a significant increase - of

\footnotetext{
14 The percentage change is calculated as $100 *$ estimate/average time spent studying by children in nonconnected households: $100 * 1.561 / 3.9198=39.8$ and $100 * 2.289 / 3.9198=58.4$.
} 
94 to 137 minutes a day - in the time children spend studying at home. This increase is greater than the average reported by the IEG (2008) (70 minutes) and the World Bank (2000) (48 minutes); other studies such as Khandker et al. (2009) find an even smaller corresponding increase of 6-8 minutes a day for Bangladesh. The IEG study points out, however, that access to electricity can also be associated with more time spent watching TV and other forms of entertainment as opposed to studying.

Going further, the benefits of rural electrification can be approximated in monetary terms. Beltrán (2013) shows that an additional hour of study by children aged 3-12 years reduces the likelihood of their repeating a grade by 1.6 percentage points. If the yearly cost per student at rural public schools is US $\$ 2,070.70,15$ then Beltrán's estimate would imply that the government saves US\$33.13 $(=2,070.7 \times 0.016)$ annually in terms of children who have not had to repeat a year. If the measured benefit of an electricity connection at the national level is $1.56-2.29$ extra hours that children spend studying at home, then the benefit to a rural household that chooses to connect to the electricity grid amounts to US\$51.68 (=1.56 $\times 33.13)$ to US\$75.87 $(=2.29 \times 33.13)$ per child. Of course, other benefits of rural electrification, such as better lighting and access to amenities such as radio/TV and refrigeration, could also be added to this. ${ }^{16}$

This cross-sectional analysis has two shortcomings. First, the survey used was conducted during December to March, which overlaps with term breaks. This may have led to biased answers concerning the time children report studying at home. Second, given the time constraint involved, the survey could not collect data on other dependent variables that measure schooling outcomes such as numeracy, reading skills and the extent to which exposure to radio and TV facilitates language learning. Finally, the current extent of rural electrification coverage - 78 percent, as reported by the MEM (2015) - implies there is still room for expanding access to electricity, especially given the potential impact of this expansion on meeting the education-related Millennium Development Goals.

\footnotetext{
${ }^{15}$ Based on data from the education ministry (http://escale.minedu.gob.pe/) and an exchange rate of PEN2.8 per US\$1.0.

${ }^{16}$ See Urrunaga et al. (2013), who calculate the cost of providing rural electrification were calculated considering benefits of illumination and radio \& TV (using consumer excedent and avoided costs methodologies) and of education (using matching techniques),
} 


\section{References}

Angrist, J. D., Imbens, G. W., \& Rubin, D. B. (1996). Identification of causal effects using instrumental variables. Journal of the American Statistical Association, 91(434), 444-455.

Angrist, J. D., \& Pischke, J.-S. (2009). Mostly harmless econometrics: An empiricist's companion. Princeton, NJ: Princeton University Press.

Asian Development Bank. (2010). Asian Development Bank's assistance for rural electrification in Bhutan - Does electrification improve the quality of rural life? (IES No. BHU 2010-27). Manila: Author.

Barnes, D. F., Peskin, H. M., \& Fitzgerald, K. (2003). The benefits of rural electrification in India: Implications for education, household lighting and irrigation. Unpublished manuscript, World Bank, Washington, DC.

Beltrán, A. (2013). El tiempo de la familia es un recurso escaso: ¿Cómo afecta su distribución el desempeño escolar? Apuntes Revista de Ciencias Sociales, 40(72), 117-156.

Bensch, G., Kluve, J., \& Peters, J. (2011). Impacts of rural electrification in Rwanda (Discussion Paper No. 6195). Bonn: Institute for the Study of Labor.

Cabraal, R. A., Barnes, D. F., \& Agarwal, S. G. (2005). Productive uses of energy for rural development. Annual Review of Environment and Resources, 30, 117-144.

Imbens, G. W., \& Angrist, J. D. (1994). Identification and estimation of local average treatment effects. Econometrica, 62(2), 467-476.

Independent Evaluation Group. (2008). The welfare impact of rural electrification: A reassessment of the costs and benefits. Washington, DC: World Bank.

Khandker, S., Barnes, D. F., \& Samad, H. A. (2009). Welfare impacts of rural electrification: A case study from Bangladesh (Policy Research Working Paper No. 4859). Washington, DC: World Bank.

Khandker, S., Barnes, D. F., \& Samad, H. A. (2013). Welfare impacts of rural electrification: A panel data analysis from Vietnam. Economic Development and Cultural Change, 61(3), 659-692. 
Khandker, S., Samad, H. A., Ali, R., \& Barnes, D. F. (2012). Who benefits most from rural electrification? Evidence in India (Policy Research Working Paper No. 6095). Washington, DC: World Bank.

Madon, G., \& Oey-Gardiner, M. (2002). EnPoGen study in Indonesia. ENERGIA News, 5(3), 11-13.

Martins, J. (2005). The impact of the use of energy sources on the quality of life of poor communities. Social Indicators Research, 72(3), 373-402.

Massé, R., \& Samaranayake, M. R. (2002). EnPoGen study in Sri Lanka. ENERGIA News, 5(3), 14-16.

Meier, P., Tuntivate, V., Barnes, D. F., ... Farchy, D. (2010). Peru: National survey of rural household energy use (Energy and Poverty Special Report No. 007/10). Washington, DC: World Bank.

Ministerio de Energía y Minas del Perú. (2015). Plan nacional de electrificación rural (PNER): Periodo 2016-2025. Lima: Dirección General de Electrificación Rural.

Peters, J. (2009). Evaluating rural electrification projects: Methodological approaches. Well-Being and Social Policy, 5(2), 25-40.

Peters, J., \& Vance, C. (2011). Rural electrification and fertility: Evidence from Côte d'Ivoire. Journal of Development Studies, 47(5), 753-766.

Ravallion, M. (2008). Evaluating anti-poverty programs. In T. P. Schultz \& J. Strauss (Eds.), Handbook of development economics, vol. 4 (chap. 59). Amsterdam: North-Holland.

Straub, S. (2015). Policy lessons from the recent literature on transport infrastructure development. In A. Picot, M. Florio, N. Grove \& J. Kranz (Eds.), The economics of infrastructure provisioning: The changing role of the state (pp. 267-284). Cambridge, MA: MIT Press.

Urrunaga, R., Bonifaz, J. L., Aguirre, J., Aragón, G., \& Jara, O. (2013). Beneficios sociales de la electrificación rural: Metodologías y estimaciones (Documento de Trabajo 91). Lima: Universidad del Pacífico, Centro de Investigación.

World Bank. (2000). Reducing the cost of grid extension for rural electrification (ESMAP Report No. 227). Washington, DC: Author. 
World Bank. (2002). Rural electrification and development in the Philippines: Measuring the social and economic benefits (ESMAP Report No. 255). Washington, DC: Author. 
Appendix

Table A1: Time allocated to reading, TV and radio

\begin{tabular}{lccc}
\hline Variable (hours spent) & With connection & Without connection & p-value \\
\hline Reading & 4.565000 & 3.504132 & 0.0000 \\
Watching TV & 2.521531 & 2.283784 & 0.1306 \\
Listening to the radio & 1.733333 & 2.306931 & 0.0004 \\
\hline
\end{tabular}

Source: Author's calculations.

Table A2: Calculation of topographic distances

\begin{tabular}{llllr}
\hline Department & \multicolumn{1}{c}{ Province } & \multicolumn{1}{c}{ District } & \multicolumn{1}{c}{ Population center } & $\begin{array}{r}\text { Distance } \\
\text { (km) }\end{array}$ \\
& & Abancay & Atunpata & 0.03 \\
\hline Apurimac & Abancay & Abancay & Quisapata & 3.72 \\
Apurimac & Abancay & Abancay & Wiracochapata & 1.60 \\
Apurimac & Abancay & Acari & Lucasi & 1.40 \\
Arequipa & Caraveli & Acari & Santa Teresa & 1.14 \\
Arequipa & Caraveli & Atico & Chorrillos & 10.85 \\
Arequipa & Caraveli & Bella Union & San Isidro & 0.00 \\
Arequipa & Caraveli & Lomas & Costa Azul & 0.01 \\
Arequipa & Caraveli & Lomas & Santa Sarita & 0.01 \\
Arequipa & Caraveli & Yauca & Alto Tupac & 0.01 \\
Arequipa & Caraveli & Yauca & Yauca & 0.01 \\
Arequipa & Caraveli & Ichocan & Illuca & 6.48 \\
Cajamarca & San Marcos & Ichocan & Llanupacha & 0.10 \\
Cajamarca & San Marcos & Ichocan & Paucamarca & 3.73 \\
Cajamarca & San Marcos & Ichocan & Paucamayo & 3.58 \\
Cajamarca & San Marcos & Ichocan & Poroporito & 0.08 \\
Cajamarca & San Marcos & Pedro Galvez & Catagon & 0.40 \\
Cajamarca & San Marcos & Pedro Galvez & Pomabamba & 2.84 \\
Cajamarca & San Marcos & Pedro Galvez & Rancho Grande & 0.04 \\
Cajamarca & San Marcos & Catilluc & Catilluc & 0.52 \\
Cajamarca & San Miguel & Catilluc & Catilluc Bajo & 0.20 \\
Cajamarca & San Miguel & Caicay & Ccollataro & 0.06 \\
Cuzco & Paucartambo & Paucartambo & Phuyucalla & 0.02 \\
Cuzco & Paucartambo & Acraquia & Mucuro & 2.30 \\
Huancavelica & Tayacaja & Acraquia & Pamuri & 0.04 \\
Huancavelica & Tayacaja & Acraquia & San Cristobal & 0.13 \\
Huancavelica & Tayacaja & Acraquia & Tomanya & 0.06 \\
Huancavelica & Tayacaja & Salcabamba & Caymo & 0.06 \\
Huancavelica & Tayacaja & Salcabamba & Garcia Pampa & 1.33 \\
Huancavelica & Tayacaja & & &
\end{tabular}




\begin{tabular}{|c|c|c|c|c|}
\hline Department & Province & District & Population center & $\begin{array}{c}\text { Distance } \\
(\mathbf{k m})\end{array}$ \\
\hline Huanuco & Huamalies & Jacas Grande & Nuevas Flores & 0.20 \\
\hline Huanuco & Huamalies & Llata & Buena Vista & 5.02 \\
\hline Huanuco & Huamalies & Llata & Libertad & 0.46 \\
\hline Huanuco & Huamalies & Llata & Ocshash & 0.01 \\
\hline Huanuco & Huamalies & Llata & Sacuatuna & 1.34 \\
\hline Ica & Chincha & Chincha Baja & Salinas & 0.02 \\
\hline Ica & Chincha & Chincha Baja & Valencia & 0.00 \\
\hline Ica & Chincha & Chincha Baja & Vilma Leon & 0.01 \\
\hline Ica & Pisco & Independencia & $\begin{array}{l}\text { Cabeza De Toro } \\
\text { Lateral } 6\end{array}$ & 1.47 \\
\hline Ica & Pisco & Independencia & Fermin Tanguis & 1.47 \\
\hline Ica & Pisco & Independencia & Nuevo Huanuco & 1.47 \\
\hline Junin & Satipo & Mazamari & $\begin{array}{l}\text { Los Angeles De Eden } \\
\text { Alto }\end{array}$ & 0.01 \\
\hline Junin & Satipo & Mazamari & Materiato & 1.28 \\
\hline Junin & Satipo & Mazamari & Mirador De Cañete & 0.15 \\
\hline Junin & Satipo & Mazamari & $\begin{array}{l}\text { San Vicente De } \\
\text { Cañete }\end{array}$ & 0.10 \\
\hline Junin & Satipo & Rio Negro & Bajo Huahuari & 0.31 \\
\hline Junin & Satipo & Rio Negro & Centro Hauhuari & 0.16 \\
\hline Junin & Satipo & Rio Negro & Centro Huahuari & 0.16 \\
\hline Junin & Satipo & Rio Negro & $\begin{array}{l}\text { Santa Rosa De } \\
\text { Panakiari }\end{array}$ & 1.53 \\
\hline Junin & Satipo & Satipo & Alto Capiro & 0.25 \\
\hline Loreto & M. Ramon Castilla & Caballococha & Bufeo Cocha & 8.72 \\
\hline Loreto & M. Ramon Castilla & Caballococha & Nuevo Palestina & 6.03 \\
\hline Loreto & M. Ramon Castilla & Yavari & Fujimori & 59.31 \\
\hline Loreto & M. Ramon Castilla & Yavari & Rondinha Zona I & 57.53 \\
\hline Loreto & M. Ramon Castilla & Yavari & Santa Rosa & 47.15 \\
\hline Pasco & Oxapampa & Oxapampa & Arcuzazu & 0.04 \\
\hline Pasco & Oxapampa & Oxapampa & El Abra & 0.50 \\
\hline Pasco & Oxapampa & Oxapampa & Quillazu & 0.40 \\
\hline Piura & Sullana & Lancones & El Cortezo & 0.30 \\
\hline Piura & Sullana & Lancones & Pampas Quemadas & 3.20 \\
\hline Piura & Sullana & Lancones & Sausal & 5.00 \\
\hline Piura & Sullana & Sullana & Cieneguillo Norte & 1.92 \\
\hline Piura & Sullana & Sullana & Las Lomas & 1.21 \\
\hline Piura & Sullana & Sullana & Las Mercedes & 0.04 \\
\hline Piura & Sullana & Sullana & $\begin{array}{l}\text { San Juan De Los } \\
\text { Ranchos }\end{array}$ & 16.48 \\
\hline Piura & Sullana & Sullana & Santa Rosa & 3.30 \\
\hline Piura & Sullana & Sullana & Tres Compuertas & 0.04 \\
\hline
\end{tabular}




\begin{tabular}{|c|c|c|c|c|}
\hline Department & Province & District & Population center & $\begin{array}{c}\text { Distance } \\
(\mathbf{k m})\end{array}$ \\
\hline Puno & Huancane & Cojata & Bellapampa & 4.82 \\
\hline Puno & Huancane & Cojata & Tomapirhua & 2.41 \\
\hline Puno & Huancane & Huancane & Bellapampa & 4.82 \\
\hline Puno & Huancane & Huancane & Chacacruz & 0.01 \\
\hline Puno & Huancane & Huancane & Taurahuta & 0.03 \\
\hline Puno & Huancane & Huatasani & Catarani & 6.68 \\
\hline Puno & Huancane & Huatasani & Ccancco & 1.28 \\
\hline Puno & Huancane & Huatasani & Curupampa & 6.10 \\
\hline Puno & Huancane & Huatasani & Huatapata & 1.28 \\
\hline Puno & Huancane & Huatasani & Llinquipata & 0.46 \\
\hline Puno & Huancane & Huatasani & Quencha Milliraya & 0.05 \\
\hline Puno & Huancane & Huatasani & San Calvario Pongoni & 1.63 \\
\hline Puno & Huancane & Huatasani & Tintapata & 1.07 \\
\hline San Martin & Rioja & $\begin{array}{l}\text { Nueva } \\
\text { Cajamarca }\end{array}$ & Angaiza & 0.20 \\
\hline San Martin & Rioja & $\begin{array}{l}\text { Nueva } \\
\text { Cajamarca }\end{array}$ & La Primavera & 1.45 \\
\hline San Martin & Rioja & $\begin{array}{l}\text { Nueva } \\
\text { Cajamarca }\end{array}$ & Palestina & 0.12 \\
\hline San Martin & Rioja & $\begin{array}{l}\text { Nueva } \\
\text { Cajamarca }\end{array}$ & Vista Alegre & 0.03 \\
\hline San Martin & Rioja & Pardo Miguel & El Afluente & 10.19 \\
\hline San Martin & Rioja & Pardo Miguel & San Juan Del Mayo & 2.95 \\
\hline Ucayali & Coronel Portillo & Yarinacocha & 11 De Agosto & 1.00 \\
\hline Ucayali & Coronel Portillo & Yarinacocha & Aahh La Capirona & 0.06 \\
\hline Ucayali & Coronel Portillo & Yarinacocha & Aahh Monterrico & 0.06 \\
\hline Ucayali & Coronel Portillo & Yarinacocha & Jose Olaya & 0.23 \\
\hline Ucayali & Coronel Portillo & Yarinacocha & $\begin{array}{l}\text { Las Damas De } \\
\text { Milagro }\end{array}$ & 0.06 \\
\hline Ucayali & Coronel Portillo & Yarinacocha & San Francisco & 0.23 \\
\hline Ucayali & Coronel Portillo & Yarinacocha & San Jose & 0.00 \\
\hline Ucayali & Coronel Portillo & Yarinacocha & San Juan & 0.01 \\
\hline Ucayali & Coronel Portillo & Yarinacocha & San Lorenzo & 0.30 \\
\hline Ucayali & Coronel Portillo & Yarinacocha & Santa Rosa & 0.10 \\
\hline Ucayali & Padre Abad & Curimana & Arenal Grande & 17.55 \\
\hline Ucayali & Padre Abad & Curimana & Arenalillo & 17.55 \\
\hline Ucayali & Padre Abad & Curimana & Sol Naciente & 4.00 \\
\hline
\end{tabular}

Source: OSINERGMIN. 